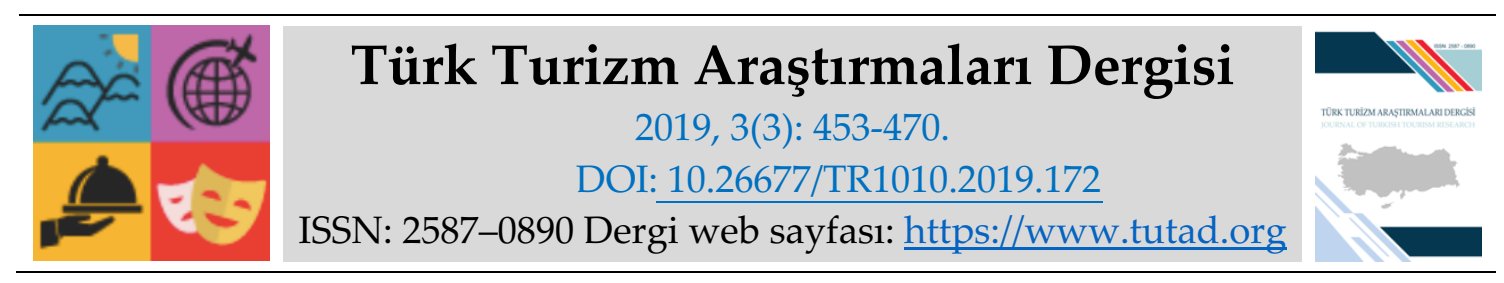

ARASTTIRMA MAKALESI

\title{
Mutfak Departmanında Kronizmin İş Tatmini ve İşten Ayrılma Niyeti Üzerindeki Etkileri: Marmaris Örneği
}

Dr. Öğr. Üyesi Alper KURNAZ, Bolu Abant İzzet Baysal Üniversitesi, Turizm Fakültesi, Bolu, eposta: alperkurnaz@gmail.com

ORCID: https://orcid.org/0000-0001-5288-0706

$\ddot{\mathrm{O} z}$

Eş-dost kayırmacılığı olarak literatüre geçen kronizm günümüzde hemen hemen birçok alanda karşılaşılan bir durum haline gelmiştir. Araştırmada turizm sektörü içinde yer alan konaklama işletmelerinin mutfak departmanları kronizm açısından ele alınmaktadır. Bu doğrultuda mutfak departmanı çalışanlarının kronizm algısı ile iş tatmini ve işten ayrılma niyeti değişkenleri arasındaki ilişkiyi incelemek amacıyla araştırma gerçekleştirilmiştir. Araştırma evrenini Muğla'da faaliyet gösteren konaklama işletmelerinin mutfak departmanı çalışanları oluşturmaktadır. Örneklem ise Marmaris konaklama işletmeleri mutfak departmanlarıdır. Araştırma da belirlenen hipotezler, korelasyon ve regresyon analizi ile test edilmiştir. Araştırma sonucunda kronizmin her bir boyutunun (işlem kronizmi, terfide kronizm, işe alma sürecinde kronizm, ücret kronizmi, performans değerlemede kronizm) işten ayrılma niyeti ile anlamlı bir ilişki içinde olduğu, iş tatmini boyutu ile ise negatif yönlü ve anlamlı bir ilişki içinde olduğu tespit edilmiştir.

Anahtar Kelimeler: Mutfak Departmanı, Kronizm, İş Tatmini, İşten Ayrılma Niyeti, Marmaris.

Makale Gönderme Tarihi: 03.05.2019

Makale Kabul Tarihi: 09.07.2019

\section{Önerilen Atıf:}

Kurnaz, A. (2019). Mutfak Departmanında Kronizmin İş Tatmini ve İşten Ayrılma Niyeti Üzerindeki Etkileri: Marmaris Örneği, Türk Turizm Araştırmaları Dergisi, 3(3): 453-470.

(C) 2019 Türk Turizm Araştırmaları Dergisi. 


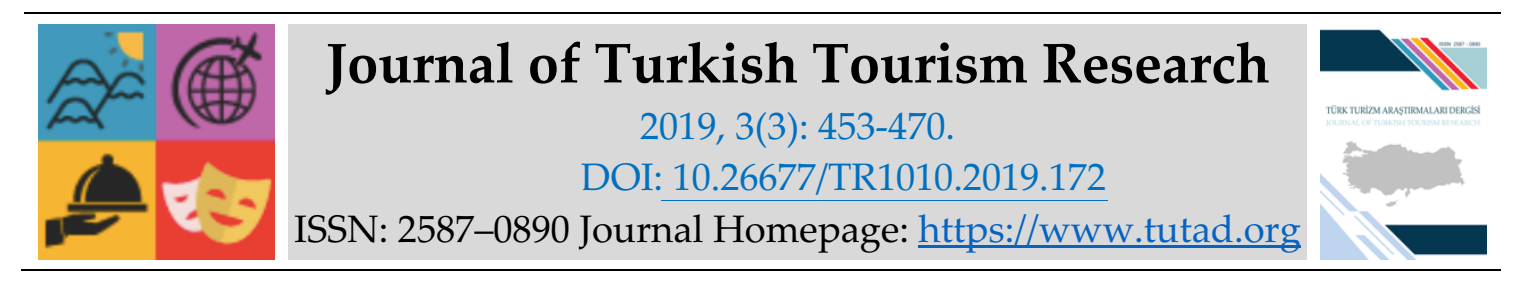

\title{
$\underline{\text { RESEARCH PAPER }}$
}

\section{The Effects of Chronism on Job Satisfaction and Intention to Quit the Job in The Kitchen Department: The Example of Marmaris}

Assistant Prof. Dr. Alper KURNAZ, Bolu Abant İzzet Baysal University, Faculty of Tourism, Bolu, e-mail: alperkurnaz@gmail.com ORCID: https://orcid.org/0000-0001-5288-0706

\begin{abstract}
Chronism in the literature as co-favored nepotism has become a situation encountered in many areas today. In this research, the kitchen departments of the hospitality companies within the tourism sector are discussed in terms of chronology. In this context, the study was conducted to investigate the relationship between the chronism perception of the employees of the kitchen department and the variables of job satisfaction and intention to leave. The research universe consists of kitchen departments in Muğla accommodation establishments. The sample is Marmaris accommodation businesses kitchen departments. The hypotheses were tested by correlation and regression analysis and the results were obtained. As a result of the study, it was found that each dimension of chronism (process chronism, chronism in promotion, chronism in the recruitment process, wage chronism, chronism in performance evaluation) has a meaningful relationship with the intention to leave the job, and it has a negative and significant relationship with the job satisfaction dimension.
\end{abstract}

Keywords: Kitchen Department, Chronism, Job Satisfaction, Intention to Leave, Marmaris. Received: 03.05.2019

Accepted: 09.07.2019

\section{Suggested Citation:}

Kurnaz, A. (2019). The Effects of Chronism on Job Satisfaction and Intention to Quit the Job in The Kitchen Department: The Example of Marmaris, Journal of Turkish Tourism Research, 3(3): 453470.

(C) 2019 Türk Turizm Araştırmaları Dergisi. 


\section{Gíriş}

İş hayatında rekabetin getirdiği "fırsatçı" olma kavramı, gelişmekte olan ülkeler için farklı biçimlerde karşımıza çıkmaktadır. Etik olmadığı bilinmesine rağmen, "kayırmacılık" ne yazık ki önlenemeyen bir gerçekliktir (Barut, 2015). Her sektörde olduğu gibi insan kaynağının önemli olduğu turizm sektöründe de insan kaynağ seçimi işletmeler için hayati derecede önem arz etmektedir. Etik olmayan bir süreçle iş görenlerin seçilmesi işletmelerde çalışanlar arasında motivasyon bozucu olarak algilanmakta bu durum da nihai ürün olan hizmetin kalitesine yansımaktadır.

Konaklama işletmeleri bünyesinde birçok departmanı bulundurmaktadır. İnsan kaynaklarından güvenlik departmanına, finansal yönetimden yiyecek içecek departmanına kadar işlemenin niteliğine ve niceliğine bağlı olarak farklı departmanlar işletmeleri oluşturmaktadır. Bu departmanlardan biri de mutfak departmanıdır. Özellikle belirli bir bilgi birikimine ve deneyime ihtiyaç duyulan bu departmanda kalifiye personele olan ihtiyaç bu departman yöneticileri tarafından üzerinde durulan önemli bir konu haline gelmiştir. Bu noktada insan kaynağının seçiminden başlayarak işten ayrılma sürecine kadar geçen zaman diliminde iş görenlerin yaşamış oldukları deneyimler, işletmelerin başarı durumlarını doğrudan etkilemektedir. İş görenlerin motivasyonları, yapmış oldukları işten aldıkları tatmin ve işten ayrılma niyetleri arasındaki ilişkiler işletmelerin örgütsel başarısı açısından anahtar rol oynamaktadır. Bu amaçla iş görenlerin kronizm algıları ile iş tatmini ve işten ayrılma niyetleri arasındaki ilişkiler araştırmanın ana amacını oluşturmaktadır.

Çalışmada giriş bölümünden sonra, kronizm, iş tatmini ve işten ayrılma niyeti kavramları ilgili literatür taraması ile elde edilen bilgiler aktarılarak açıklanmaya çalışılmıştır. Ayrıca bu konular ile ilgili daha önce yapılmış olan çalışmalar hakkında özet bilgiler ve araştırma hipotezleri de bu bölümde yer almaktadır. Metodoloji bölümü ile araştırmanın amacı ve yöntemi hakkında bilgiler verilmektedir. Bu bölümden sonra verilerin analizlerine yer verilmektedir. Sonuç ve tartışma kısmında, araştırma sonucu elde edilen bulgular ve hipotezlerin değerlendirilmesi gerçekleştirilmiştir. Ayrıca araştırmadan çıkan genel sonuç ve öneriler de burada aktarılmaktadır.

\section{LITERATÜR TARAMASI VE ARAŞTIRMANIN HIPOTEZLERİ}

Kronizm kavramı, Yunanca "khronios", İngilizce "crony" kelimelerinden gelmekte ve uzun süreli arkadaşlık, dostluk anlamına karşlık gelmektedir (Özer ve Çağlayan, 2016). Kronizm kelimesinin Türkçe karşılığı olarak kullanılabilen en temel sözcük "kayırmacılık" olarak ifade edilebilir. "Kayırmacılık" kavramı temel anlamda Türk Dil Kurumu Büyük Türkçe Sözlüğü (2019)'nde İngilizce bir kelime olan "favoritism" kökünden "Belli bir birey, küme, düşünce ya da uygulamayı, bir başkasıyla karşılaştırıp aralarında bir seçim yapmak gerektiğinde nesnellikten uzaklaşıp yan tutma" şeklinde tanımlanmıştır. Kronizm, insanların yetenekleri, bilgileri ile değil de kişisel ilişkilere, kişilerarası bağlantıya dayanarak bir yerlere geldiği ve sonuçta insanların verimliliğini ve performansını düşürdüğü bir gerçeklik olarak tanımlanabilmektedir (Khatri vd., 2003). Bazen iş görenlerin verimliliğini artırmak için kronizm kullanılabilir. İşe alım sürecinde iş görenlerin eş-dost ilişkisi ya da kişisel bağlantı ile işe alındıklarında, yüksek performans göstermeleri beklenir, bu da kurumlardaki diğer insanları daha iyi performans göstermeleri için motive edebilir.

Kronizm birçok örgütte gerçekleştiği bilinmektedir. Yapılan araştırmalar, kronizmin yalnızca kamu sektörü örgütlerinde değil, aynı zamanda özel sektör örgütlerinde de iş doyumu ile ilişkisinin negatif bir bağlantısı olduğunu göstermiştir (Araslı vd., 2006; Araslı ve Tümer 2008). 
Özellikle hizmet sektörünün bir alt kolu olan turizm sektöründe de kronizm etkileri hissedilmektedir. Sektörün insan odaklı olması ve sektörde yer alan işletmelerin hizmet üretebilmesi için en çok ihtiyaç duyduğu unsurlardan birinin insan kaynağı olması ister istemez kronizme maruz kalma ihtimali artırmaktadır. İş görenlerin adil olmayan bir işe alım süreci ile işe alınması işletmelerde hali hazırda çalışan iş görenleri olumsuz etkilemektedir. Bu durum iş görenlerin motivasyonlarını düşürmekte ve sonuç olarak işten ayrılma sürecini hızlandırmaktadır.

İş tatmini, insan kaynakları literatüründe en çok çalışılan konulardan biridir. İş tatmini, "birinin mesleğinin iş değerlerini elde etmek veya kolaylaştırmak" olarak değerlendirilmesinden kaynaklanan süreç olarak tanımlanabilir (Locke, 1969). Konaklama işletmelerinde, özellikle müşterilerle direk temas halinde çalışanlar müşterilerle doğrudan etkileşime girerler ve müşteri memnuniyeti ve sadakati geliştirmede büyük rol oynarlar. Bu sebeple müşterilerle etkileşime geçen çalışanların, kaliteli hizmet sunmak ve müşterileri memnun etmek için yaptıkları işten tatmin olmaları önemlidir (Spinelli ve Canavos, 2000). Arches (1991) iş tatminini, çalışanların işlerine olan doyumları şeklinde ifade etmektedir. İş tatmini, sadece çalışanların performansını etkileyen bir süreç değil aynı zamanda işletmelerin kar elde etmeleri için de önemlidir. İş tatmini, çalışanın ücret, yönetim ve sorumluluklarla ilgili iyimser tepkisidir (Wanous ve Lawler, 1972; French, 1982; Tziner ve Vardi, 1984). Kurumların başarılı bir şekilde işletilmeleri ve maksimum kar elde etmeleri için memnun çalışanlara ihtiyacı vardır. Örgütlerin gelişimi örgütte yer alan iş görenlerin verimliliğine bağlıdır. İş tatminini etkileyen birçok faktör vardır. İş tatmini yalnızca bir faktöre bağlı değildir; biri için pozitif, diğeri için negatif olabilir (Spector, 1997). Bu faktörler uzun yıllara dayanan bilimsel çalışmalarla kuramlaşmış ve farklı yaklaşımlarla kabul görmüştür. Motivasyon araçları olarak da kabul gören bu yaklaşımlar işletme yöneticileri tarafından uygulanmakta ve işletme başarısı için önemli bir yol haritası mahiyeti taşımaktadır. İş görenin işletme performansı işletmenin başarısı ile doğru orantılıdır. Bu sebeple işletme yöneticilerinin iş görenleri motive etmede kullandıkları araçların varlığı ya da yokluğu/eksikliği hem iş gören açısından hem de işletme açısından üzerinde durulması gereken yönetsel faaliyetleri oluşturmaktadır. Motivasyon araçlarının yeterince olmaması, işletmede adalet eksikliği, iş görenler arası kayırmacılık zamanla iş görenlerin motivasyonunu bozarak sonuç olarak işletmeden ayrılmalarına sebep olmaktadır.

İşletmenin sürdürülebilir bir ömüre sahip olmasında şüphesiz iş görenlerin rolü büyüktür. İş gören devir hızının yüksek olması işletme ömrünün uzamasına engellerken bu oranın düşük olması işletme ömrünün uzamasına katkı sağlamaktadır. Bu durum turizm sektörü özelinde ele alındığında sektörün emek yoğun hizmet işletmelerden oluşması iş görenlerin işten ayrılma sürecini de hızlandırmaktadır. Bu sebeple otel işletmelerinde, iş gören devamlılığı için hem maliyetler açısından hem de işletme başarısı ve kesintisiz kaliteli hizmet açısından, diğer işletmelere göre görece olarak önemli olduğu söylenebilir (Zopiatis vd., 2014). Ayrılma niyeti, bir bireyin bir kuruluşta kalma veya ayrılma olasılığını ifade etmektedir (Cotton ve Tuttle, 1986). Tett ve Meyer (1993)'e göre kuruluştan ayrılma konusunda iş görenler bilinçli ve kasitlı bir isteklilik içindedirler. Araştırmalar, işten ayrılma niyetinde gönüllülüğün karar verme sürecinde etkili olduğunu göstermiştir (Griffeth vd., 2000; Price, 2001; Lambert vd., 2001). İşten ayrilma niyeti ile ilgili birçok örgüt içi ve örgüt dışı faktör vardır. Örgüte güven (Keleş vd., 2015), iş gören performansı (Bouckenooghe vd., 2013), örgütsel özdeşleşme (Topçu ve Basım, 2015), örgütsel adalet (Turan vd., 2019) bu faktörlerden bazılardır. Ayrıca iş görenler arasında işten ayrılma niyetini açıklayan en önemli faktörlerden biri de iş tatminidir (Biswas, 2010).

Literatürde kayırmacılı̆̆ın iş tatmini ve işten ayrılma niyeti üzerindeki etkisini araştıran birçok çalışma bulunmaktadır. İş tatmini ve işten ayrılma niyetinin değerlendirilmesi ile ilgili konaklama işletmeleri sınır birim çalışanları üzerine yapılan bir araştırmada iş tatmini ve işten 
ayrılma niyeti arasında anlamlı ve negatif yönde bir ilişki olduğu ifade edilmektedir (Sökmen ve Ceyhun Sezgin, 2017). Psikolojik sermaye, performans, ayrılma niyeti ve iş tatmini etkileşimi ile ilgili cinsiyetin düzenleyici rolü üzerine yürütülen çalışmada psikolojik sermayenin işten ayrılma

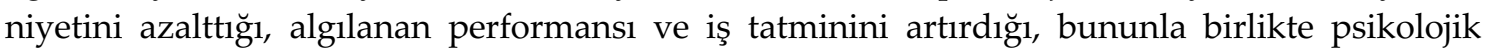
sermaye ile işten ayrılma niyeti ilişkisinde iş tatmininin bir aracılık rolü olduğu belirlenmiştir (Çetin ve Varoğlu, 2015). Kadın çalışanlarda cam tavan yansıtıcılarından kurum ikliminin, iş tatmini ve işten ayrılma niyetine etkisi ile ilgili konaklama işletmelerinde bir araştırma yapılmış, araştırma sonucunda örgüt iklimi ile işten ayrılma niyeti arasında anlamlı ve pozitif yönlü bir ilişki ve etki tespit edilmiştir (Sökmen ve Akar Şahingöz, 2017). İş yaşamında iş tatmini, örgütsel özdeşleme ve işten ayrılma niyeti ile ilgili Erzurum'da bir kamu kurumunda yapılan çalışmada iş tatmini ile işten ayrılma niyeti arasında ve örgütsel özdeşleşeme ile işten ayrılma niyeti arasında ise negatif yönlü ilişki görülmüştür (Çınar vd., 2016). Medya yöneticilerinin iş tatmin düzeylerinin işten ayrılma niyetleri üzerindeki etkisi ile ilgili yürütülen çalışmada medya yöneticilerinin sahip oldukları içsel iş tatmini ve dışsal iş tatmini düzeylerinin işten ayrılma niyetleri üzerinde negatif etkiye sahip olduğu bulgusuna ulaşılmıştır (Karaca vd., 2017). Bu bilgilerden hareketle literatürde iş tatmini ve işten ayrılma niyeti ile ilgili farklı alanlarda çalışmaların yapılmış olduğu görülmekle birlikte konu kapsamında kronizm algılarının iş tatmini ve işten ayrılma niyeti üzerindeki etkilerini belirlemeye yönelik geliştirilen hipotez şu şekilde ifade edilebilir:

Hipotez 1: Kronizm algılarını oluşturan her bir boyut, (H1a: genel kronizm algıları, H1b: işlem kronizmi, H1c: terfide kronizm, H1d: işe alma sürecinde kronizm, H1e: ücret kronizmi, H1f: performans değerlemede kronizm) iş tatmini üzerinde etkilidir.

Hipotez 2: Kronizm algılarını oluşturan her bir boyut, (H1a: genel kronizm algıları, H1b: işlem kronizmi, H1c: terfide kronizm, H1d: işe alma sürecinde kronizm, H1e: ücret kronizmi, H1f: performans değerlemede kronizm) işten ayrılma niyeti üzerinde etkilidir.

\section{ARAŞTIRMANIN AMACI VE YÖNTEMİ}

Bu bölümde, araştırmanın amacı ve kapsamı, araştırmanın örneklemi ve kullanılan veri toplama aracı hakkında bilgiler yer almaktadır. İş görenlerin kronizm algıları ile iş tatmini ve işten ayrılma niyetleri arasındaki ilişkilerin tespiti araştırmanın amacını oluşturmaktadır. Gerçekleştirilen bu araştırmada iş görenlerin kronizm boyutları ile iş tatmini ve işten ayrılma niyeti ile ilgili ifadelerden ne algıladıklarının belirlenmesinin yanı sıra bu faktörler arasındaki etki düzeylerinin de ölçülmesi hedeflenmiştir. Bu doğrultuda oluşturulan araştırma modeli (Şekil 1) şu şekildedir: 


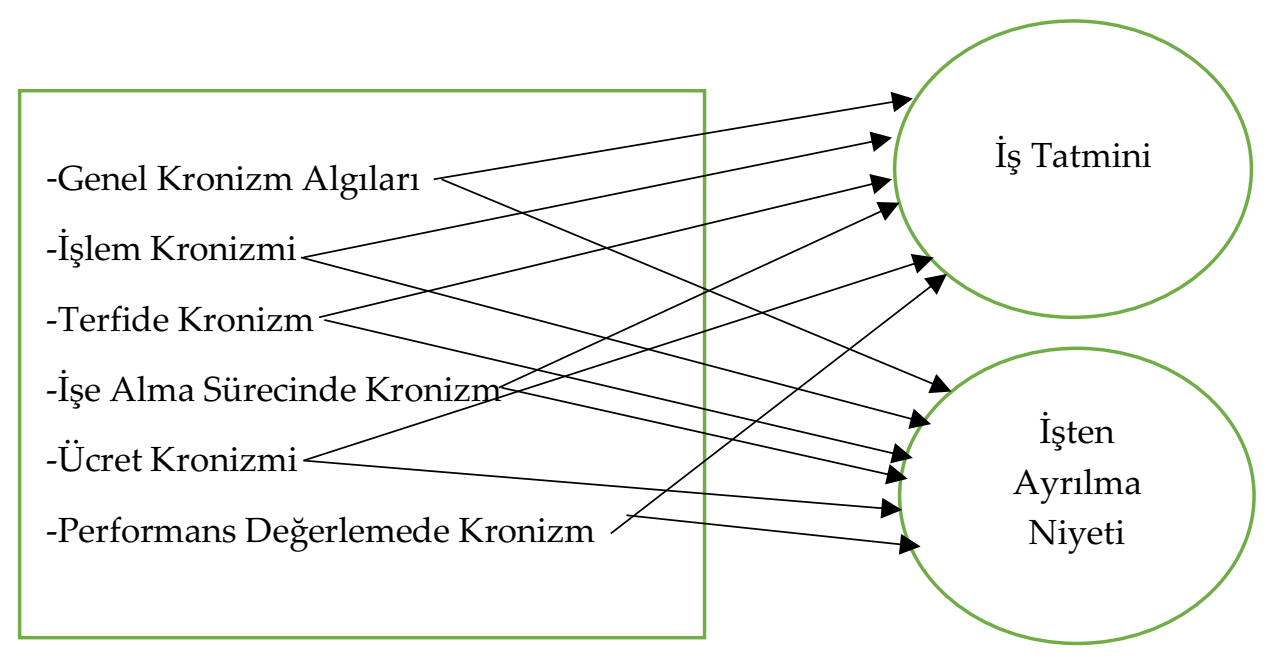

Şekil 1. Araştırma Modeli

\section{Evren ve Örneklem}

Araştırmanın evrenini Marmaris ilçe merkezinde yer alan konaklama işletmelerinin mutfak departmanı çalışanları oluşturmaktadır. Marmaris'te işletme belgeli; 3 adet tatil köyü, 16 adet beş yıldızlı otel, 25 adet dört yıldızlı otel, 30 adet üç yıldızlı otel, 12 adet iki yıldızlı, 1 adet bir yıldızlı otel, 25 adet apart otel ve 2 adet butik otel olmak üzere toplam 114 konaklama işletmesi yer almaktadır. Ayrıca yatırım belgeli; 1 adet tatil köyü, 4 adet beş yıldızlı, 6 adet dört yıldızlı, 4 adet üç yıldızlı, 2 adet bir yıldızlı ve 4 adet butik otel olmak üzere toplam 21 adet konaklama işletmesi vardır. Marmaris'te işletme ve yatırım belgeli toplamda 135 konaklama işletmesi bulunmaktadır (Muğla İl Kültür ve Turizm Müdürlügüu, 2019). Ana külteyi temsilen örneklem seçiminde olasılıksız örneklem yöntemlerinden kolayda örnekleme yöntemi tercih edilmiştir. Örneklemden elde edilen verilerin tüm ana kütleyi yansıtamama kısıtı bulunmaktadır. Örneklemin ana kütleyi temsil etme oranını belirlemek amacıyla araştırmacılar farklı yaklaşımlar önermektedir. Bazı araştırmacılar ölçekte yer alan madde sayısının 10 katı örneklem olması gerektiğini savunurken (Nunnally, 1978); bazı araştırmacılar 4 katı olmasının yeterli olduğunu ifade etmektedir (MacCallum vd., 2001). Madde sayısının en az 5 katı olması gerektiğini savunan araştırmacılar da literatürde görülmektedir (Tavşancıl, 2006; Doğan ve Başokçu, 2010). Bu araştırmada kullanılan ölçekte madde sayısının 46 olduğu düşünüldügünnde elde edilen anket sayısının 286 olması istatistiki işlemler için yeterli sayıya ulaşıldığı şeklinde ifade edilebilir.

\section{Veri Toplama Aracı}

Verilerin elde edilmesinde veri toplama yöntemi olarak anket tekniği kullanılmıştır. Araştırmada kullanılan anket formunda tanımlayıcı bilgiler, genel kronizm algıları, iş tatmini ve işten ayrılma niyeti bölümleri yer almaktadır. Araştırma ölçeğinin hazırlanması amacıyla literatür taraması sonucunda Karataş (2013)'ın otel işletmelerinde kronizmin iş tatmini ve işten ayrılma niyeti üzerine etkisinin anlaşılabilmesi için geliştirdiği ölçek kullanılmıştır. Anket formu dört bölümden oluşmaktadır. İlk bölümde iş görenlerle ilgili tanımlayııı bilgileri elde etmek amacıyla 9 soru yer almaktadır. İkinci bölümde genel kronizm algıları ölçeği ile ilgili 28 önerme yer almaktadır. Üçüncü bölümde iş tatmini ile ilgili 3 önerme son bölümde ise işten ayrılma niyeti ile ilgili 6 önerme formda kullanılmıştır. 5'li Likert tipi derecelendirme ölçeği kullanılmış olup 1-Kesinlikle Katılmıyorum, 5-Kesinlikle Katılıyorum'u ifade etmektedir. Karataş (2013) tarafından yapılan araştırmada kronizm algıları 6 boyut olarak değerlendirilmiştir. Bunlar; genel kronizm algıları, 
işlem kronizmi, terfide kronizm, işe alma sürecinde kronizm, ücret kronizmi, performans değerlemede kronizmdir. Bu araştırmada yapılan analizler Karataş (2013) tarafından belirlenen boyutlar üzerinden değerlendirmeye tabi tutulmuştur.

\section{Veri Toplama Süreci}

Ölçeğin daha önce kullanılmış olması geçerlilik güvenilirlik sorununu ortadan kaldırmaktadır. Ancak ölçeğin daha önce konaklama işletmelerinde kullanılması sebebiyle araştırma konusuna uygunluk göstermesi ve ölçeğin yapı geçerliliğinin sağlanabilmesi için önermelerde düzenlemeler yapılmıştır. Bu amaçla yiyecek içecek alanında çalışmaları olan bir akademisyen ile iki mutfak şefi tarafından anket formu değerlendirilmiş, yapılan düzenlemeler sonrasında ölçek örneklem üzerinde uygulanmıştır. Çalışma evrenine uygun olarak 16 Eylül 2018 - 30 Ekim 2018 tarihleri arasında anketler uygulanmış, analize uygun olmadığı tespit edilen 17 anket çıkartılarak 286 anket analize tabi tutulmuştur.

\section{ARAŞTIRMANIN BULGULARI}

Araştırma sonucu elde edilen verilerin değerlendirilmesi ve araştırmanın amacına uygun olarak oluşturulan hipotezlerin sınanması bu bölümde yer almaktadır.

Tablo 1. Katılımcların Tanımlayıcı Bilgileri

\begin{tabular}{|l|l|l|l|l|l|}
\hline Cinsiyet & Frekans & Yüzde & İşletme Deneyimi & Frekans & Yüzde \\
\hline Kadın & 87 & 30,4 & $2-4$ & 191 & 66,8 \\
\hline Erkek & 199 & 69,6 & $5-7$ & 52 & 18,2 \\
\hline Eğitim & Frekans & Yüzde & $8-10$ & 21 & 7,3 \\
\hline İlköğretim & 33 & 11,5 & 11 ve üstü & 22 & 7,6 \\
\hline Lise & 78 & 27,3 & Yaş & Frekans & Yüzde \\
\hline Ön lisans & 138 & 48,3 & 20 ve altı & 89 & 31,1 \\
\hline Lisans & 32 & 11,2 & $21-30$ & 103 & 36,0 \\
\hline Lisansüstü & 5 & 1,7 & $31-40$ & 46 & 16,1 \\
\hline Departman & Frekans & Yüzde & $41-50$ & 41 & 14,3 \\
\hline $\begin{array}{l}\text { Soğuk } \\
\text { mutfak }\end{array}$ & 61 & 21,3 & 51 ve üstü & 7 & 2,4 \\
\hline Sicak mutfak & 72 & 25,2 & Sektör Deneyimi & Frekans & Yüzde \\
\hline Alakart & 60 & 21,0 & $2-4$ & 102 & 35,7 \\
\hline Kahvaltı & 21 & 7,3 & $5-7$ & 80 & 28,0 \\
\hline $\begin{array}{l}\text { Personel } \\
\text { mutfağ1 }\end{array}$ & 13 & 4,5 & $8-10$ & 45 & 15,7 \\
\hline Pastane & 38 & 13,3 & 11 ve üstü & 59 & 20,6 \\
\hline Diğger & 21 & 7,3 & & & \\
\hline
\end{tabular}

Araştırmanın verileri IBM SPSS 22.0 istatistik paket programı kullanılarak analiz edilmiştir. Araştırma amacına yönelik oluşturulan hipotezler \%95 güven aralığında test edilmiştir. Araştırmada yer alan katılımcıların cinsiyet, yaş, eğitim düzeyi, işletme deneyimi, çalıştıkları departman ve sektör deneyimlerine yönelik tanımlayıcı bilgiler yukarıda Tablo $1^{\prime}$ de sunulmaktadir. 
Katılımcıların \%30,4'ü kadınlardan, \%69,6'sı erkeklerden oluşmaktadır. Katılımcıların neredeyse yarısı ön lisans mezunudur. Katılımcıların daha çok sıcak mutfak, soğuk mutfak ve alakart departmanında çalıştıkları görülmektedir. Bununla birlikte pastane, kahvaltı, personel mutfağı ve diğer departmanlarda çalışan katılımcılar araştırmada yer almaktadır. İşletme deneyimi olarak katılımcların daha çok 2-4 yıllık deneyime sahip olduğu görülmektedir. Yaş aralığında ise 20 yaş altı ve 21-30 yaş aralığı çoğunluğu oluşturmaktadır. Sektör deneyimi olarak katılımcıların daha çok 2-4 ve 5-7 yıllık deneyime sahip katılımcıların yoğunluğu dikkati çekmektedir.

Tablo 2. İş Görenlerin Kayırmacılık Algıları

\begin{tabular}{|c|c|c|c|}
\hline Soru & Değişken & Frekans & Yüzde \\
\hline \multirow{2}{*}{$\begin{array}{l}\text { Kayırmacilık } \\
\text { Var mi? }\end{array}$} & Evet & 144 & 50,3 \\
\hline & Hayır & 142 & 49,7 \\
\hline \multirow{4}{*}{$\begin{array}{l}\text { İşletme Sahibi } \\
\text { veya } \\
\text { İşletmecisi ile } \\
\text { Yakınlığınız }\end{array}$} & $\begin{array}{l}\text { İşletme Sahip veya Kurucusuyla Hiçbir Kan Bağı } \\
\text { Yakınlığım Yok }\end{array}$ & 236 & 82,5 \\
\hline & Arkadaşım / Dostum & 30 & 10,5 \\
\hline & $\begin{array}{l}\text { Diğer Akrabalarım (anne, baba ve kardeş hariç } \\
\text { diğerleri) }\end{array}$ & 4 & 1,5 \\
\hline & Babam / Annem / Kardeşim & 16 & 5,5 \\
\hline \multirow{5}{*}{$\begin{array}{l}\text { İş görenlere } \\
\text { Yapılan } \\
\text { Kayırmacılık } \\
\text { Türleri }\end{array}$} & Bazı Çalışanların Mekân/Oda/Yer Avantajları Var. & 99 & 34,6 \\
\hline & $\begin{array}{l}\text { Bazı iş görenler Daha Esnek Çalışma Saatlerine } \\
\text { Sahiptir. }\end{array}$ & 103 & 36,0 \\
\hline & Bazı Personel Daha Fazla İzin Alabilmektedir. & 51 & 17,8 \\
\hline & $\begin{array}{l}\text { Bazı iş görenlerin Kullandıkları araç ve gereçler (örn. } \\
\text { bıçak seti, önlük) daha iyi / daha yenidir. }\end{array}$ & 23 & 8,0 \\
\hline & Diğer & 10 & 3,5 \\
\hline
\end{tabular}

Katılımcıların çalışmakta oldukları işletmedeki deneyimlerinden yola çıkarak kayırmacılıkla ilgili değerlendirmeleri Tablo 2' de görülmektedir. "İşletmenizde kayırmacılık var mı?" sorusuna katılımcıların \%50,3'ü evet cevabı verirken, \%49,7'si hayır cevabı vermiştir. “İşletme sahibi veya işletmecisi ile yakınlığınız nedir?" sorusuna katılımcların \%82,5'i işletme sahip veya kurucusuyla hiçbir kan bağı yakınlığım yok cevabını vermiştir. "İş görenlere yapılan kayırmacılık türleri nelerdir? sorusuna katılımcıların \%36'sı "bazı iş görenler daha esnek çalışma saatlerine sahip" cevabını vermiştir. Yine bu değerlendirmeye $\% 34,6$ 'lik bir oranla yakın olan "bazı çalışanların mekân/oda/yer avantajları var." ifadesi dikkati çekmektedir.

Tablo 3. Kronizm Ölçeklerinin Güvenilirlik Katsayıları

\begin{tabular}{|l|c|c|}
\hline Ölçekler & $\begin{array}{c}\text { Cronbach's Alpha } \\
(\boldsymbol{\alpha})\end{array}$ & Önerme Sayısı \\
\hline Genel Kronizm Algıları & 0,859 & 7 \\
\hline İşem Kronizmi & 0,897 & 7 \\
\hline Terfide Kronizm & 0,903 & 5 \\
\hline İsse Alma Sürecinde Kronizm & 0,889 & 4 \\
\hline Ücret Kronizmi & 0,814 & 3 \\
\hline Performans Değerlemede Kronizm & 0,786 & 2 \\
\hline İş Tatmini & 0,876 & 3 \\
\hline İșten Ayrilma Niyeti & 0,914 & 5 \\
\hline Tüm Değişkenler & 0,955 & 37 \\
\hline
\end{tabular}


Tablo 3 ele alındığında, tüm ölçekte yer alan 37 önermenin güvenilirlik katsayısın 0,955 olduğu görülmektedir. Tüm ölçek grup bazında ele alındığında tüm ölçeklerin alfa değerleri 0,786 ile 0,914 arasında değişmektedir. Bu ifadeden hareketle tüm ölçeğin iç tutarlılık sağladığı görülmektedir.

Tablo 4. Önerme Bazında Tüm Ölçeğe İlişkin Aritmetik Ortalama ve Standart Sapmalar

\begin{tabular}{|c|c|c|c|}
\hline $\begin{array}{l}\text { Ölçek } \\
\text { Grupları }\end{array}$ & Önermeler & $\begin{array}{l}\text { Aritmetik } \\
\text { Ortalama }\end{array}$ & $\begin{array}{c}\text { Standart } \\
\text { Sapma }\end{array}$ \\
\hline \multirow{7}{*}{$\begin{array}{l}\text { Genel } \\
\text { Kronizm } \\
\text { Algiları }\end{array}$} & $\begin{array}{l}\text { Eş - dost / arkadaş kayırmacılığı, bu işyerinde sıkça } \\
\text { tartışılan konulardan biridir. }\end{array}$ & 2,75 & 1,37 \\
\hline & $\begin{array}{l}\text { Yönetimde tanıdığı olan iş görenlerin yanında ne } \\
\text { söylediğime dikkat ederim. }\end{array}$ & 3,15 & 1,47 \\
\hline & $\begin{array}{l}\text { Bu işletmede bazı iş görenler, yönetim } \\
\text { kademesindeki kişilerle arkadaşlık ilişkilerinden } \\
\text { dolayı işe alınmışlardır. }\end{array}$ & 3,10 & 1,30 \\
\hline & $\begin{array}{l}\text { Eş - dost / arkadaş kayırmacılığı, örgüt çalışanlarının } \\
\text { motivasyonunu olumsuz yönde etkiler. }\end{array}$ & 3,49 & 1,39 \\
\hline & $\begin{array}{l}\text { Bu işletmenin değerleri, eş - dost / arkadaş } \\
\text { kayırmacıllı̆ına dayalıdır. }\end{array}$ & 2,76 & 1,28 \\
\hline & $\begin{array}{l}\text { Bu işyerindeki geleceğim, eş - dost / arkadaş } \\
\text { kayırmacılığına dayalı ilişkilerden dolayı oldukça } \\
\text { sinırlıdır. }\end{array}$ & 2,82 & 1,33 \\
\hline & $\begin{array}{l}\text { Bu işletmede yöneticiler, kendi tanıdıkları / } \\
\text { arkadaşları olan iş görenlerin fikirlerine daha fazla } \\
\text { değer vermektedir. }\end{array}$ & 3,05 & 1,25 \\
\hline \multirow{7}{*}{$\begin{array}{l}\text { İşlem } \\
\text { Kronizmi }\end{array}$} & $\begin{array}{l}\text { Bu işletmenin yönetim kadrosunda tanıdığı / } \\
\text { arkadaşı olan çalışanlar, diğer kişilerden itibar } \\
\text { görmektedir. }\end{array}$ & 2,94 & 1,31 \\
\hline & $\begin{array}{l}\text { Bu işletmede, yöneticilerin tanıdıklarını / } \\
\text { arkadaşlarını işten çıkarmanın veya onlara ceza } \\
\text { vermenin oldukça zor olduğunu düşünüyorum. }\end{array}$ & 3,10 & 1,28 \\
\hline & $\begin{array}{l}\text { Bu işletmede yetki ve sorumluluk, öncelikle } \\
\text { yöneticilerin tanıdıklarına / arkadaşlarına } \\
\text { devredilmektedir. }\end{array}$ & 2,86 & 1,32 \\
\hline & $\begin{array}{l}\text { Bu işletmenin yönetim kademesinde tanıdığı / } \\
\text { arkadaşı olanlar, işletmenin kaynaklarından daha } \\
\text { kolay yararlanmaktadır. }\end{array}$ & 3,05 & 1,25 \\
\hline & $\begin{array}{l}\text { Bu işletmede yöneticilerin arkadaşı konumunda olan } \\
\text { çalışanların, diğer çalışanlara göre bir ayrıcalığı } \\
\text { vardır. }\end{array}$ & 2,96 & 1,33 \\
\hline & $\begin{array}{l}\text { Bu işletmede, yöneticilerin tanıdığı / arkadaşı olan } \\
\text { kişilerden çekinirim. }\end{array}$ & 2,58 & 1,32 \\
\hline & $\begin{array}{l}\text { Departman yöneticileri, üst yönetimle arkadaşlık } \\
\text { ilişkileri olan çalışanlardan çekinirler. }\end{array}$ & 2,85 & 1,26 \\
\hline $\begin{array}{l}\text { Terfide } \\
\text { Kronizm }\end{array}$ & $\begin{array}{l}\text { Bu işletmede çalışanların terfi ettirilmesinde, } \\
\text { yöneticilerle olan arkadaşlık ilişkileri öncelikle } \\
\text { dikkate alınır. }\end{array}$ & 2,95 & 1,32 \\
\hline
\end{tabular}




\begin{tabular}{|c|c|c|c|}
\hline & $\begin{array}{l}\text { Bu işletmede, işletme yöneticilerinin tanıdıklarının / } \\
\text { arkadaşlarının terfi etmesinin daha kolay olduğunu } \\
\text { düşünüyorum. }\end{array}$ & 3,07 & 1,28 \\
\hline & $\begin{array}{l}\text { Bu işletmede çalışanların terfi etmesinde bilgi, beceri } \\
\text { ve kabiliyetler ikinci planda kalmaktadır. }\end{array}$ & 3,05 & 1,28 \\
\hline & $\begin{array}{l}\text { Bu işletmede yöneticiler, işletmeye katkısına veya } \\
\text { performansına bakmaksızın, kendi tanıdıklarını veya } \\
\text { arkadaşlarını daha iyi pozisyona getirmektedirler. }\end{array}$ & 3,05 & 1,22 \\
\hline & $\begin{array}{l}\text { Bu işletmede ne kadar başarılı olursam olayım, } \\
\text { işletme yöneticilerinin tanıdıklarının / arkadaşlarının } \\
\text { önüne geçemem. }\end{array}$ & 2,85 & 1,30 \\
\hline & $\begin{array}{l}\text { Bu işletmeye eleman alımında, işletme yönetiminin } \\
\text { arkadaşları / tanıdıkları önceliklidir. }\end{array}$ & 3,15 & 1,27 \\
\hline İşe Alma & $\begin{array}{l}\text { Bu işletmede bazı görevlere, yalnızca işletme } \\
\text { sahibinin veya yöneticisinin arkadaşları / tanıdıkları } \\
\text { getirilmektedir. }\end{array}$ & 3,01 & 1,31 \\
\hline Kronizm & $\begin{array}{l}\text { Bu işletmeye eleman alımında, işletmede tanıdığı / } \\
\text { arkadaşı olanlar seçim sürecinde zorlanmazlar. }\end{array}$ & 3,12 & 1,22 \\
\hline & $\begin{array}{l}\text { Bu işletmedeki bir boş pozisyona, yöneticinin } \\
\text { herhangi bir tanıdığı / arkadaşı başvuru yaptığında, } \\
\text { hemen işe alınır. }\end{array}$ & 3,07 & 1,28 \\
\hline & $\begin{array}{l}\text { Bu işletmede eş - dost / arkadaş kayırmacıllı̆ına } \\
\text { dayalı bir ücret politikası vardır. }\end{array}$ & 2,86 & 1,30 \\
\hline $\begin{array}{l}\text { Ücret } \\
\text { Kronizmi }\end{array}$ & $\begin{array}{l}\text { Bu işletmede, tüm çalışanlar için geçerli adil bir } \\
\text { ücretlendirme politikası olduğunu düşünmüyorum. }\end{array}$ & 3,02 & 1,33 \\
\hline & $\begin{array}{l}\text { Bu işletmede uygulanan ücret politikasında, } \\
\text { arkadaşlık ilişkileri söz konusudur. }\end{array}$ & 2,84 & 1,27 \\
\hline Performans & $\begin{array}{l}\text { Bu işletmede, objektif bir performans değerlemeden } \\
\text { bahsedilemez. }\end{array}$ & 2,97 & 1,22 \\
\hline $\begin{array}{l}\text { Değerlemede } \\
\text { Kronizm }\end{array}$ & $\begin{array}{l}\text { Bu işletmede performans değerlemesi yapılırken, } \\
\text { yöneticilerin tanıdıklarına / arkadaşlarına ayrıcalık } \\
\text { tanınır. }\end{array}$ & 2,94 & 1,23 \\
\hline & İşimi severek yaparım & 4,10 & 1,35 \\
\hline İş Tatmini & Mutluluğu işimdeyken buluyorum & 3,83 & 1,27 \\
\hline & Mevcut işimden çok memnunum & 3,80 & 1,33 \\
\hline & Daha iyi bir iş bulur bulmaz ayrılacağım. & 2,33 & 1,35 \\
\hline & Her an istifa kararı verebilirim. & 2,13 & 1,30 \\
\hline $\begin{array}{l}\text { Işten } \\
\text { Avrrlma }\end{array}$ & Şu anda aktif bir şekilde dışarıda iş arıyorum. & 2,11 & 1,38 \\
\hline Ayrmind & Alternatif iş tekliflerini kabul edebilirim. & 2,78 & 1,43 \\
\hline & Ciddi bir biçimde işten ayrılmayı düşünüyorum. & 2,09 & 1,30 \\
\hline & Sıklıkla işimden ayrılmayı düşünüyorum. & 2,12 & 1,32 \\
\hline
\end{tabular}

Tablo 4 değerlendirildiğinde, iş görenlerin kronizm algılarının 5'li Likert ölçeğinin "katılmıyorum" ve "karasızım" seçenekleri arasında gerçekleştiği görülmektedir. Sadece "İşimi severek yaparım" önermesinde "katılıyorum" seçeneğinin değerlendirilmesi ise dikkati çekmektedir. Genel kronizm algıları ölçeğinde en yüksek oran 3,49 ile "Eş - dost / arkadaş kayırmacıllğı̆, örgüt çalışanlarının motivasyonunu olumsuz yönde etkiler" önermesinde olmuştur. İş görenlerin kararsız olduğu görülmektedir. En düşük oran ise 2,75 ile "Eş - dost / 
arkadaş kayırmacılığı, bu işyerinde sıkça tartışılan konulardan biridir" önermesindedir. Bu oran iş görenlerin bu ifadeye katılmadıklarını göstermektedir.

İşlem kronizmi ölçeğinde ise en yüksek oran 3,10 ile "Bu işletmede, yöneticilerin tanıdıklarını / arkadaşlarını işten çıkarmanın veya onlara ceza vermenin oldukça zor olduğunu düşünüyorum" önermesidir. Bu önermeye katılımda kararsız katılımcılar çoğunluğu oluşturmaktadır. En düşük oran ise "Bu işletmede, yöneticilerin tanıdığı / arkadaşı olan kişilerden çekinirim" önermesidir. $\mathrm{Bu}$ önermeye katılımcılar katılmadıklarını belirtmişlerdir.

Terfide kronizm ölçeğinde ise en yüksek oran 3,07 ile "Bu işletmede, işletme yöneticilerinin tanıdıklarının / arkadaşlarının terfi etmesinin daha kolay olduğunu düşünüyorum" önermesidir. Kararsız katılımcılar ortalamayı oluşturmaktadır. En düşük oran ise 2,85 "Bu işletmede ne kadar başarılı olursam olayım, işletme yöneticilerinin tanıdıklarının / arkadaşlarının önüne geçemem" önermesidir. Katılımcılar bu önermeye katılmadıklarını ifade etmişlerdir.

İşe alma sürecinde kronizm ölçeğinde tüm oranlarda katılımcıların karasız olduğu görülmektedir. En yüksek oranın 3,15 ile "Bu işletmeye eleman alımında, işletme yönetiminin arkadaşları / tanıdıkları önceliklidir" önermesi ve en düşük oranın 3,01 ile "Bu işletmede bazı görevlere, yalnızca işletme sahibinin veya yöneticisinin arkadaşları / tanıdıkları getirilmektedir" önermesi şeklinde değerlendirildiği görülmektedir.

Ücret kronizmi ölçeğinde en yüksek oran 3,02 ile "Bu işletmede, tüm çalışanlar için geçerli adil bir ücretlendirme politikası olduğunu düşünmüyorum" önermesidir. Karasızlık ön plandadır. En düşük oran ise 2,84 ile "Bu işletmede uygulanan ücret politikasında, arkadaşlık ilişkileri söz konusudur" önermesidir.

Performans değerlemede kronizm ölçeğinde ise iki önerme yer almak ve bu iki önermede de katılımcılar önermelere katılmadıklarını ifade etmektedirler. "Bu işletmede, objektif bir performans değerlemeden bahsedilemez" önermesi 2,97 oranına, "Bu işletmede performans değerlemesi yapılırken, yöneticilerin tanıdıklarına / arkadaşlarına ayrıcalık tanınır" önermesi 2,94 oranına sahiptir.

İş tatmini ölçeğinin aritmetik ortalamasına bakıldığında en yüksek oranın 4,10 ile "İşimi severek yaparım" önermesi başı çekmektedir. İş görenlerin yaptığı işten memnun oldukları söylenebilir. En düşük oran ise 3,80 ile "Mevcut işimden çok memnunum" önermesidir. Her ne kadar kararsızım ortalaması dikkati çekse de katılıyorum seçeneğine yakın bir ortalama iş görenlerin memnun oldukları şeklinde yorumlanabilir.

İşten ayrılma niyeti aritmetik ortalamaları incelendiğinde tüm önermelere kararsız katılım ifadesi dikkati çekmektedir. En yüksek oran 2,78 ile "Alternatif iş tekliflerini kabul edebilirim" önermesidir. En düşük oran ise 2,09 ile "Ciddi bir biçimde işten ayrılmayı düşünüyorum" önermesidir. $\mathrm{Bu}$ ifadeler ile iş görenlerin yaptıkları işe devam etme niyetinde oldukları söylenebilir.

\section{Korelasyon Analizi}

Kronizm ölçeğinin her bir boyutu ile iş tatmini ve işten ayrılma niyeti arasında ilişki olup olmadığını ölçmek amacıyla korelasyon analizi gerçekleştirilmiştir. 
Tablo 5. Değişkenler Arasındaki İlişki Testi Sonuçları

\begin{tabular}{|c|c|c|c|c|c|c|c|c|}
\hline Değişkenler & 1 & 2 & 3 & 4 & 5 & 6 & 7 & 8 \\
\hline $\begin{array}{l}\text { Genel } \\
\text { Kronizm } \\
\text { Alg1ları } \\
\end{array}$ & 1 & & & & & & & \\
\hline $\begin{array}{l}\text { İşlem } \\
\text { Kronizmi }\end{array}$ & $\begin{array}{l}0,807^{*} \\
(0,000)\end{array}$ & 1 & & & & & & \\
\hline $\begin{array}{l}\text { Terfide } \\
\text { Kronizm }\end{array}$ & $\begin{array}{l}0,734^{*} \\
(0,000)\end{array}$ & $\begin{array}{l}0,838^{*} \\
(0,000)\end{array}$ & 1 & & & & & \\
\hline $\begin{array}{l}\text { İşe Alma } \\
\text { Sürecinde } \\
\text { Kronizm }\end{array}$ & $\begin{array}{l}0,746^{*} \\
(0,000)\end{array}$ & $\begin{array}{l}0,830^{*} \\
(0,000)\end{array}$ & $\begin{array}{l}0,838^{*} \\
(0,000)\end{array}$ & 1 & & & & \\
\hline $\begin{array}{l}\text { Ücret } \\
\text { Kronizmi }\end{array}$ & $\begin{array}{l}0,595^{*} \\
(0,000)\end{array}$ & $\begin{array}{l}0,706^{*} \\
(0,000)\end{array}$ & $\begin{array}{l}0,717^{*} \\
(0,000)\end{array}$ & $\begin{array}{l}0,733^{*} \\
(0,000)\end{array}$ & 1 & & & \\
\hline $\begin{array}{l}\text { Performans } \\
\text { Değerlemede } \\
\text { Kronizm } \\
\end{array}$ & $\begin{array}{l}0,633^{*} \\
(0,000)\end{array}$ & $\begin{array}{l}0,746^{*} \\
(0,000)\end{array}$ & $\begin{array}{l}0,765^{*} \\
(0,000)\end{array}$ & $\begin{array}{l}0,755^{*} \\
(0,000)\end{array}$ & $\begin{array}{l}0,794^{*} \\
(0,000)\end{array}$ & 1 & & \\
\hline İş Tatmini & $\begin{array}{c}0,53 \\
(0,369) \\
\end{array}$ & $\begin{array}{c}0,29 \\
(0,630) \\
\end{array}$ & $\begin{array}{c}0,21 \\
(0,725) \\
\end{array}$ & $\begin{array}{c}0,42 \\
(0,484) \\
\end{array}$ & $\begin{array}{c}-0,16 \\
(0,791) \\
\end{array}$ & $\begin{array}{c}0,009 \\
(0,873) \\
\end{array}$ & 1 & \\
\hline $\begin{array}{l}\text { İşten Ayrılma } \\
\text { Niyeti }\end{array}$ & $\begin{array}{l}0,307^{*} \\
(0,000)\end{array}$ & $\begin{array}{l}0,348^{*} \\
(0,000)\end{array}$ & $\begin{array}{l}0,390^{*} \\
(0,000)\end{array}$ & $\begin{array}{l}0,372^{*} \\
(0,000)\end{array}$ & $\begin{array}{l}0,313^{*} \\
(0,000)\end{array}$ & $\begin{array}{l}0,318^{*} \\
(0,000)\end{array}$ & $\begin{array}{l}-0,374^{*} \\
(0,000)\end{array}$ & 1 \\
\hline
\end{tabular}

*Korelasyon 0,01 düzeyinde anlamlıdır. (2-tailed).

Tablo 5'te görüldüğü üzere, kronizmin her bir boyutunun işten ayrılma niyeti ile anlamlı bir ilişki içinde olduğu, iş tatmini boyutu ile ise negatif yönlü ve anlamlı bir ilişki içinde olduğu görülmektedir. Kronizm ile iş tatmini boyutunda ise anlamlı bir ilişki görülmemektedir. İşten ayrılma niyeti ile kronizm boyutları arasında ise $p<0,01$ düzeyinde anlamlı ve pozitif yönlü, işten ayrılma niyeti ile iş tatmini arasından ise $r=-0,374$ ve $p<0,01$ düzeyinde anlamlı ve negatif yönlü bir ilişki vardır. Erdem ve Karataş (2015) tarafından yapılan çalışmada ise kronizmin hem iş tatmini hem de işten ayrılma niyeti ile ilişkisi tespit edilmiştir.

\section{Hipotez Testleri}

Araştırmanın amacı doğrultusunda oluşturulan hipotezlere ilişkin basit doğrusal regresyon analizleri gerçekleştirilmiştir. Hipotez testleri ile ilgili analiz sonuçlar Tablo 6'da ve Tablo 7' de verilmektedir.

Tablo 6 incelendiğinde iş tatmininin kronizm algılarını oluşturan hiçbir boyut üzerinde anlamlı etkisinin olmadığı tespit edilmiştir. Bu veriler doğrultusunda $\mathrm{H} 1$ hipotezleri reddedilmiştir.

Tablo 7 incelendiğinde işten ayrılma niyeti ile kronizm algılarını oluşturan her bir boyut üzerinde anlamlı bir etkisinin olduğu görülmektedir. Bu veriler ile $\mathrm{H} 2$ hipotezleri (H2a: genel kronizm algıları, H2b: işlem kronizmi, H2c: terfide kronizm, H2d: işe alma sürecinde kronizm, H2e: ücret kronizmi, H2f: performans değerlemede kronizm, H2g: kronizm ölçeği toplam) kabul edilmiştir.

Araştırma analiz sonuçlarına göre iş tatmini ile kronizm algılarını oluşturan her bir boyut üzerinde anlamlı bir etkisinin olmadığı görülürken; işten ayrılma niyeti ile kronizm algılarını oluşturan her bir boyut üzerinde anlamlı bir etkisinin olduğu görülmektedir. Kronizm algılarının işten ayrılma niyeti üzerindeki etkileri sırasıyla incelendiğinde; terfide kronizm $(\beta=0,390$; 
$\mathrm{p}<0.01)$, işe alma sürecinde $\operatorname{kronizm}(\beta=0,372 ; \mathrm{p}<0.01)$, işlem kronizmi $(\beta=0,348 ; \mathrm{p}<0.01)$, performans değerlemede $\operatorname{kronizm}(\beta=0,318 ; \mathrm{p}<0.01)$, ücret kronizmi $(\beta=0,313 ; \mathrm{p}<0.01)$ son olarak genel kronizm algıları $(\beta=0,307 ; p<0.01)$ yer almaktadır. Araştırma hipotezlerinin sonuçları durumları Şekil 2'de araştırma modeli üzerinde gösterilmiştir.

Tablo 6. Kronizm Algılarını Oluşturan Her Bir Boyut ile İş Tatmini Üzerindeki Etkisini Ölçmek Amaciyla Yapilan Regresyon Analizi

\begin{tabular}{|c|c|c|c|c|c|c|}
\hline \multicolumn{7}{|c|}{ Bağımsız Değișken: İș Tatmini } \\
\hline $\begin{array}{l}\text { Bağımlı } \\
\text { Değişken }\end{array}$ & $\mathrm{R}^{2}$ & $\mathrm{~F}$ & $\beta$ & $\mathrm{t}$ & $\mathrm{p}$ & $\begin{array}{l}\text { Durbin } \\
\text { Watson }\end{array}$ \\
\hline $\begin{array}{l}\text { Genel Kronizm } \\
\text { Algiları }\end{array}$ & 0,003 & 0,808 & 0,053 & 0,899 & 0,369 & 1,481 \\
\hline İşlem Kronizmi & 0,001 & 0,233 & 0,029 & 0,483 & 0,630 & 1,484 \\
\hline Terfide Kronizm & 0,000 & 0,124 & 0,021 & 0,352 & 0,725 & 1,490 \\
\hline $\begin{array}{l}\text { İşe Alma } \\
\text { Sürecinde } \\
\text { Kronizm } \\
\end{array}$ & 0,002 & 0,491 & 0,042 & 0,701 & 0,484 & 1,487 \\
\hline Ücret Kronizmi & 0,000 & 0,070 & $-0,016$ & $-0,265$ & 0,791 & 1,500 \\
\hline $\begin{array}{l}\text { Performans } \\
\text { Değerlemede } \\
\text { Kronizm } \\
\end{array}$ & 0,000 & 0,025 & 0,009 & 0,160 & 0,873 & 1,494 \\
\hline $\begin{array}{l}\text { Kronizm Ölçeği } \\
\text { Toplam }\end{array}$ & 0,001 & 0,288 & 0,032 & 0,537 & 0,592 & 1,485 \\
\hline
\end{tabular}

Tablo 7. Kronizm Algılarını Oluşturan Her Bir Boyut ile İşten Ayrılma Niyeti Üzerindeki Etkisini Ölçmak Amaciyla Yapılan Regresyon Analizi

\begin{tabular}{|l|c|c|c|c|c|c|}
\hline \multicolumn{7}{|l|}{ Bağımsız Değişken: İşten Ayrılma Niyeti } \\
\hline $\begin{array}{l}\text { Bağımlı } \\
\text { Değişken }\end{array}$ & $\mathrm{R}^{2}$ & $\mathrm{~F}$ & $\beta$ & $\mathrm{t}$ & $\mathrm{p}$ & $\begin{array}{c}\text { Durbin } \\
\text { Watson }\end{array}$ \\
\hline $\begin{array}{l}\text { Genel Kronizm } \\
\text { Algıları }\end{array}$ & 0,094 & 29,598 & 0,307 & 5,440 & 0,000 & 1,663 \\
\hline İşlem Kronizmi & 0,121 & 39,163 & 0,348 & 6,258 & 0,000 & 1,677 \\
\hline Terfide Kronizm & 0,152 & 50,805 & 0,390 & 7,128 & 0,000 & 1,638 \\
\hline $\begin{array}{l}\text { İşe Alma } \\
\text { Sürecinde } \\
\text { Kronizm }\end{array}$ & 0,138 & 45,590 & 0,372 & 6,752 & 0,000 & 1,651 \\
\hline Ücret Kronizmi & 0,098 & 30,842 & 0,313 & 5,554 & 0,000 & 1,644 \\
\hline $\begin{array}{l}\text { Performans } \\
\text { Değerlemede } \\
\text { Kronizm }\end{array}$ & 0,101 & 32,039 & 0,318 & 5,660 & 0,000 & 1,624 \\
\hline $\begin{array}{l}\text { Kronizm Ölçeği } \\
\text { Toplam }\end{array}$ & 0,147 & 48,804 & 0,383 & 6,983 & 0,000 & 1,658 \\
\hline
\end{tabular}




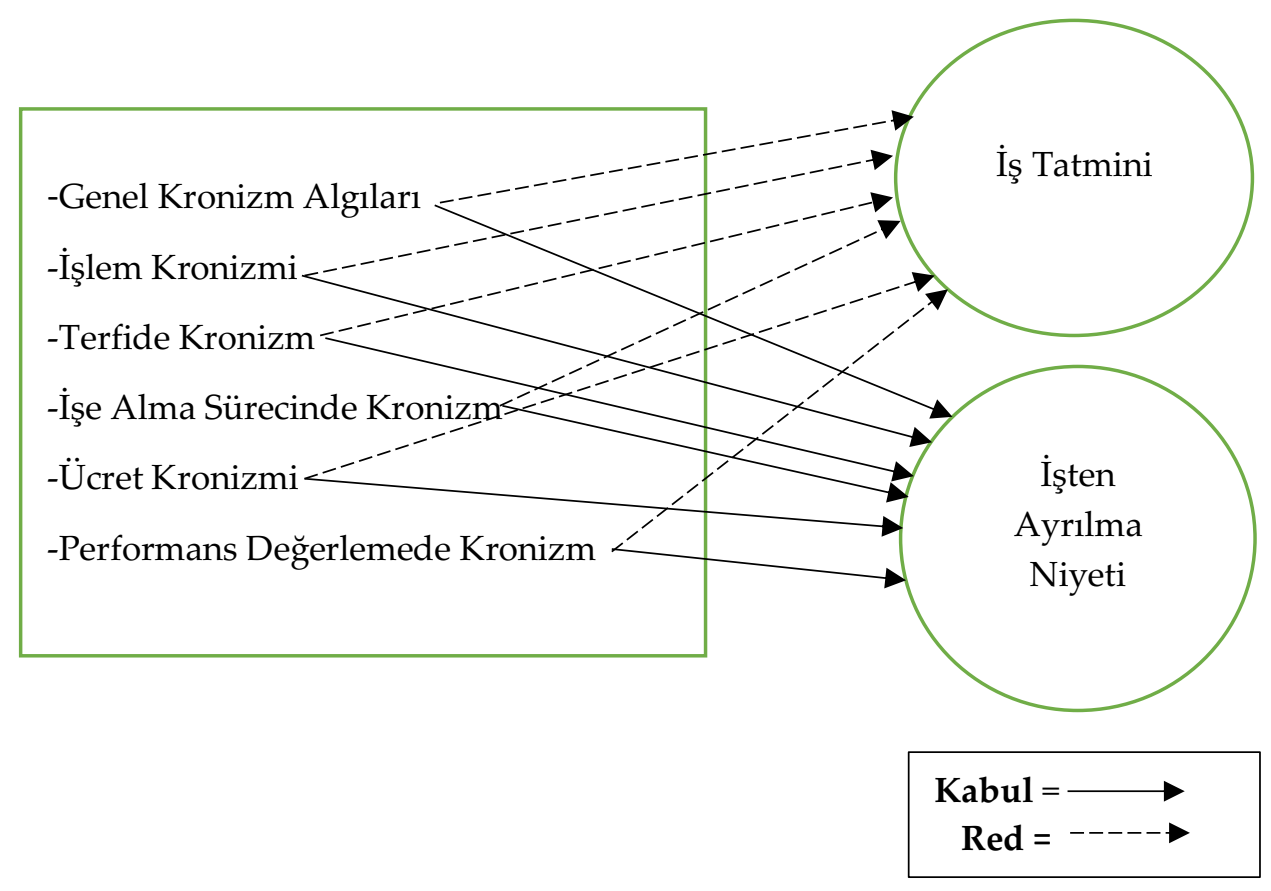

Şekil 2. Hipotez Testi Sonuçlarına İlişkin Şematik Gösterim

\section{TARTIŞMA, SONUÇ ve ÖNERİLER}

Bu araştırmada mutfak departmanında çalışan iş görenlerin kronizm algıları ile iş tatmini ve işten ayrılma niyeti üzerindeki etkileri ölçülmeye çalışılmıştır. Başka bir ifade ile mutfak departmanı çalışanlarının eş-dost kayırmacılığı algıları ile ne ölçüde bir iş tatmini sağladıkları ve sonuç olarak işten ayrılma niyeti üzerinde ne gibi etkilerinin olduğu araştırılmıştır.

Araştırma sonucunda iş görenlerin kronizm algıları ile iş tatmini arasında istatiksel olarak anlamlı bir ilişki görülmezken, kronizm algıları ile işten ayrılma niyeti arasında anlamlı bir ilişki görülmüştür. Kronizm boyutlarını oluşturan terfide kronizm $(\beta=0,390 ; p<0.01)$, işe alma sürecinde $\operatorname{kronizm}(\beta=0,372 ; p<0.01)$, işlem kronizmi $(\beta=0,348 ; p<0.01)$, performans değerlemede $\operatorname{kronizm}(\beta=0,318 ; \mathrm{p}<0.01)$, ücret kronizmi $(\beta=0,313 ; \mathrm{p}<0.01)$ ve genel kronizm algıları ile işten ayrılma niyeti arasında anlamlı ilişki tespit edilmiştir. Bu bilgiler ışığında araştırma örnekleminde yer alan mutfak departmanı iş görenlerinin özellikle işten ayrılmaya karar vermelerinde eş-dost kayırmacılığının etkisinin önemli bir payı olduğu düşünülmektedir. Araştırma sonucu olarak işten ayrılma niyeti üzerinde ortaya çıan kayırmacılık etkisinin literatür taramasında sırasında elde edilen bulgularla da örtüşü görülmektedir (Arye vd., 2002; Kocabaş ve Baytekin, 2004; Vural ve Sohodol, 2004; Büte, 2011; Keleş vd., 2011; Erdem ve Karataş 2015; Yücekaya vd., 2016).

İş görenler kayırmacılık ile ilgili olarak en çok esnek çalışma saatlerinde ve bazı çalışanlara mekân/oda/yer avantajı sağlandığı noktasında kayırmacılık yapıldığı ifade edilmiştir. Esnek çalışma saatlerinde yapılan kayırmacılık sonucu ile Erdem, Ceylan ve Saylan (2013) tarafından yapılan çalışmanın sonuçları örtüşmektedir. Erdem, Çeribaş ve Karataş (2013) ile Arslaner, Erol ve Boylu (2014) tarafından yapılan çalışmalarda da benzer sonuçlar görülmüştür.

Kronizm ölçeği önerme bazında ele alındığında, en yüksek ortalamaya sahip "eş - dost / arkadaş kayırmacılı̆̆ı, örgüt çalışanlarının motivasyonunu olumsuz yönde etkiler" önermesi dikkati çekmektedir. İş görenler çalışanların motivasyon kaybında kayırmacıllğın önemine vurgu 
yapmaktadırlar. En yüksek ikinci ortalamaya sahip iki önerme vardır. Bu önermelerden biri "yönetimde tanıdığı olan iş görenlerin yanında ne söylediğime dikkat ederim" ifadesidir. Bu sonuçla, iş görenlerin çalıştığı ortamda örgüt içi iletişim açısından zorlandıkları sonucuna varılabilir. Diğer önerme ise "bu işletmeye eleman alımında, işletme yönetiminin arkadaşları/tanıdıkları önceliklidir" şeklinde ifade edilmiştir. Buradan hareketle insan kaynakları açısından da kayırmacılık olduğu anlaşılmaktadır. Yeh (2013) tarafından yapılan çalışmada da benzer sonuçlar yer almaktadır.

Araştırma kapsamında elde edilen veriler doğrultusunda bazı önerilerde bulunulmaktadır. Departman yöneticileri, öncelikle çalışma saatlerinde ve iş görenlere mekan/oda/yer sağlama da adalet algılarını zedelemeyecek bir sistem oluşturmalıdırlar. İş görenlerin işten ayrılma niyetleri kayırmacılık algıları ile doğrudan etkileşim içindedir. Bu sebeple iş görenler arasında örgütsel adalete önem verilmeli, motivasyon koşulları herkes için eşit uygulanmalıdır. İş görenlere terfide daha adil sistem sunulmalı ve işe alma sürecinde eşit uygulamalar ile personel seçimi yapılmalıdır. Mutfak departmanında önemli noktalardan birinin kalifiye personel olduğu varsayıldığında adil bir sistemin varlı̆̆ı örgüt başarısını sürdürülebilir hale getirmede önemli bir etken olarak görülebilir. Örgüt içi iletişimde iş görenlerin daha kolay iletişim kurmasına zemin oluşturulmalıdır.

Araştırmanın en önemli kısıtını mutfak departmanında çalışan iş görenlerin bilimsel çalışmayı gereksiz görmeleri ve zaman ayırmada isteksiz olmaları şeklinde ifade etmek mümkündür. Araştırma sonuçları örneklemi oluşturan katılımcı görüşleri ile sınırlıdır. Araştırmanın genellenebilmesi için farklı örneklem grupları ile kıyaslamalar yapılabileceği gibi daha derinlemesine bilgi alınabilmesi için araştırma nitel araştırma yöntemleri ile de tekrarlanıp yeni bilgiler literatüre kazandırılabilir.

\section{KAYNAKÇA}

Araslı, H. and Tümer, M. (2008). Nepotism, Favoritism and Cronyism: A Study of Their Effects on Job Stress and Job Satisfaction in the Banking Industry of North Cyprus, Social Behavior and Personality, 36(9): 1237-1250.

Araslı, H., Ali, B. and Erdoğan E. H. (2006). The Effects of Nepotism on Human Resource Management: The Case of Three, Four- and Five-Star Hotels in Northern Cyprus, International Journal of Sociology and Social Policy, 26(7): $295-308$.

Arches, J. (1991). Social Structure, Burnout, and Job Satisfaction, Social Work, 36 (3): 202-206.

Arslaner, E., Erol, G. ve Boylu, Y. (2014). Konaklama İşletmelerinde Nepotizm ve Örgütsel Adalet Alg1sı Üzerine Bir Araştırma, Muğla Sıtkı Koçman Üniversitesi Sosyal Bilimler Enstitüsü Dergisi, 32(1): $62-77$.

Aryee, S., Budhwar, P. S. and Chen, Z. X. (2002). Trust as a Mediator of the Relationship Between Organizational Justice and Work Outcomes: Test of a Social Exchange Model, Journal of Organizaational Behavior, 23(3): 267-285.

Barut, B. (2015). İşyerinde İrrasyonel Davranışlar: Nepotizm, Favorizm, Kronizm Algısı Üzerine Nitel Araştırma, The Journal of Academic Social Science 3(20): 382-394.

Biswas, S. (2010). Relationship Between Psychological Climate and Turnover Intentions and Its Impact on Organisational Effectiveness: A Study in Indian Organisations, IIMB Management Review, 22, 102-110. 
Bouckenooghe, D., Raja, U. and Butt, A. N. (2013). Combined Effects of Positive and Negative Affectivity and Job Satisfaction on Job Performance and Turnover Intentions, The Journal of Psychology: Interdisciplinary and Applied, 147(2): 105-123.

Büte, M. (2011). Kayırmacılığın Çalışanlar Üzerine Etkileri ile İnsan Kaynakları Uygulamaları İlişkisi: Türk Kamu Bankalarına Yönelik Bir Araştırma, Atatürk Üniversitesi Sosyal Bilimler Enstitüsü Dergisi, 15(1): 383-404.

Cotton, J. L. and Tuttle, J. M. (1986). Employee Turnover: A Meta-Analysis and Review with Implications for Research, Academy of Management Review, 11(1): 55-70.

Çetin, F. ve Varoğlu, A. K. (2015). Psikolojik Sermaye, Performans, Ayrılma Niyeti ve İş Tatmini Etkileşimi: Cinsiyetin Düzenleyici Rolü, İş ve İnsan Dergisi, 2(2): 105-113.

Çınar, O., Karcıoğlu, F. ve Akdaş, K. (2016). İş Yaşamında İş Tatmini, Örgütsel Özdeşleme ve İşten Ayrılma Niyeti İlişkisi: Erzurum'da Bir Kamu Kurumu Örneği, Siyaset, Ekonomi ve Yönetim Araştırmaları Dergisi, 4(3): 121-136.

Doğan, N. ve Başokçu, T. (2010). İstatistik Tutum Ölçeği İçin Uygulanan Faktör Analizi ve Aşamalı, Eğitimde ve Psikolojide Ölçme ve Değerlendirme Dergisi, 1(2): 65-71.

Erdem, B., Ceylan, U. ve Saylan, U. (2013). Aile İşletmelerinde Nepotizm ve Örgütsel Bağlllık İlişkisi: Kütahya'da Faaliyet Gösteren Otel İşletmelerinde Bir Araştırma, Uludağ Üniversitesi İktisadi ve İdari Bilimler Fakültesi Dergisi, 32(2): 171-197.

Erdem, B., Çeribaş, S. ve Karataş, A. (2013). Otel İşletmelerinde Çalışan İş görenlerin Kronizm (Eş - Dost Kayırmacılı̆̆ı) Algıları: İstanbul'da Faaliyet Gösteren Bir, İki ve Üç Yıldızlı Otel İşletmelerinde Bir Araştırma, Çukurova Üniversitesi İktisadi ve İdari Bilimler Fakültesi Dergisi, 17(1): 51-69.

Erdem, B. and Karataş, A. (2015). The Effects of Cronyism on Job Satisfaction and Intention to Quit the Job in Hotel Enterprises: The Case of Three, Four- and Five-Star Hotels in Muğla, Turkey, Manas Sosyal Araştırmalar Dergisi, 4(1): 55-74.

French, W. L. (1982). The Personnel Management Process: Human Resources Administration and Management, Boston: Houghton Mifflin Company.

Griffeth, R. W., Hom, P. W. and Gaertner, S. (2000). A Meta-Analysis of Antecedents and Correlates of Employee Turnover: Update Moderator Tests, and Research Implications for The Next Millennium, Journal of Management, 26(3): 463-488.

Karaca, M., Biçkes, D. M., Çakı, C. ve Karaduman, G. (2017). Medya Yöneticilerinin İş Tatmin Düzeylerinin İşten Ayrılma Niyetleri Üzerindeki Etkisi: Malatya Örneği, Gümüşhane Üniversitesi İletişim Fakültesi Elektronik Dergisi, 5(2): 969-990.

Karataş, A. (2013). Otel İşletmelerinde Kronizmin İş Tatmini ve İşten Ayrılma Niyeti Üzerindeki Etkileri: Muğla İlinde Bir Araştırma, Yayınlanmamış Yüksek Lisans Tezi, Balıkesir Üniversitesi Sosyal Bilimler Enstitüsü, Balıkesir.

Keleş, H. N., Özkan, T. K. and Bezirci, M. (2011). A Study on The Effects of Nepotism, Favoritism and Cronyism on Organizational Trust in The Auditing Process in Family Businesses in Turkey, International Business and Economics Research Journal, 10(9): 9-16.

Khatri, N., Eric W. and Tsang, K. (2003). Antecedents and Consequences of Cronyism in Organizations, Journal of Business Ethics, 289-303. 
Kocabaş, F. ve Baytekin, E. P. (2004). Aile İşletmelerinde Nepotizm ve İç Müşteri Üzerindeki Etkileri, 1. Aile İşletmeleri Kongresi, T.C. İstanbul Kültür Üniversitesi İktisadi ve İdari Bilimler Fakültesi, 17-18 Nisan, İstanbul. ss: 424-430.

Lambert, E. G., Hogan, N. L. and Barton, S. M. (2001). The Impact of Job Satisfaction on Turnover Intent: A Test of a Structural Measureme Nt Model Using A National Sample of Workers, The Social Science Journal, 38: 233-250.

Locke, E. A. (1969). What is Job Satisfaction? Organizational Behavior and Human Performance, 4(2): 309-336.

MacCallum, R. C., Widaman, K. F., Preacher, K. J. and Hong, S. (2001). Sample Size in Factor Analysis: The Role of Model Error, Multivariate Behavioral Research, 36(4): 611-637.

Muğla İl Kültür ve Turizm Müdürlüğü (2019). İstatistikler, [Online] http://www.muglakulturturizm.gov.tr/TR-155861/bakanlik-belgeli-isletmeler.html, [Erişim Tarihi: 16.04.2019].

Nunnally, J. C. (1978). Psychometric Theory, New York: McGraw Hill.

Özer, N. and Çağlayan, Z. A. (2016). Relationship Between Teachers' Trust in Principal and Perceived Cronyism, Inonü University Journal of the Graduate School of Education, 3(5): 15-27.

Price, J. (2001). Reflections on The Determinants of Voluntary Turnover, International Journal of Manpower, 22: 600-624.

Sökmen, A ve Ceyhun Sezgin A. E. (2017). İş Tatmini ve İşten Ayrılma Niyetinin Değerlendirilmesi: Otel İşletmeleri Sınır Birim Çalışanları Üzerinde Bir Araştırma, Journal of Tourism and Gastronomy Studies, 5(2): 237-250.

Sökmen, A. ve Akar Şahingöz, S. (2017). Kadın Çalışanlarda Cam Tavan Yansıtıcılarından Kurum İkliminin, İş Tatmini ve İşten Ayrılma Niyetine Etkisi: Otel İşletmelerinde Bir Araştırma, İşletme Araştırmaları Dergisi, 9(1): 113-133.

Spector, P. E. (1997). Job Satisfaction: Application, Assessment, Causes, and Consequences. Thousand Oaks, CA: Sage Publications.

Spinelli, M. A. and Canavos, G. C. (2000). Investigating the Relationship Between Employees Satisfaction and Guest Satisfaction, Cornell Hotel \& Restaurant Administration Quarterly, 41(6): 2933.

Tavşancıl, E. (2006). Tutumların Ölçülmesi ve SPSS ile Veri Analizi. (3. Baskı), Ankara: Nobel.

Tett, R. P. and Meyer, J. P. (1993). Job Satisfaction, Organizational Commitment, Turnover Intention, And Turnover: Path Analyses Based on Meta-Analytic Findings, Personnel Psychology, 46: 259-293.

Topçu, M. ve Basım, H. N. (2015). Kobi'lerde Çalışanların Kişilik Özelliklerinin Örgütsel Özdeşleşme ve İşten Ayrılma Niyeti Üzerine Etkisinde Psikolojik Sözleşme Algısının Rolü, International Periodical for the Languages, Literature and History of Turkish or Turkic, 10(10): 861-886.

Turan, E., Demirel, Y., Çetin, S. ve Dengel, D. (2019). Örgütsel Adaletin İşten Ayrılma Niyeti Üzerine Etkisi: Özel Sektör Çalışanlarına Yönelik Bir Araştırma, Üçüncü Sektör Sosyal Ekonomi Dergisi, 54(1): 394-414.

Türk Dil Kurumu Büyük Türkçe Sözlük (2019). Kayırmacılık?, http://www.tdk.gov.tr/index.php?option=com_bts\&arama=kelime\&guid=TDK.GTS.5cadab18d7 2bc6.60987430, [Erişim Tarihi: 10.04.2019]. 
Tziner, A. E. and Vardi Y. (1984). Work Satisfaction and Absenteeism Among Social Workers: The Role of Altruistic Values, Work and Occupations, 11(4): 461-470.

Vural, B. A. ve Sohodol, Ç. (2004). Aile Şirketlerinde Kurumsal Kültür: Avantajlar-Dezavantajlar ve Öneriler Üzerine Bir Çalışma, 1. Aile İşletmeleri Kongresi, T.C. İstanbul Kültür Üniversitesi İktisadi ve İdari Bilimler Fakültesi, 17-18 Nisan, İstanbul, ss: 324-332.

Wanous, J. P. and Lawler, E. E. (1972). Measurement and Meaning of Job Satisfaction, Journal of Applied Psychology, 56(2): 95-104.

Yeh, M. C. (2013). Tourism Involvement, Work Engagement and Job Satisfaction Among Frontline Hotel Employees, Annals of Tourism Research, 42: 214-239.

Yücekaya, P., Rençber, Ö. F. and Topçu, U. C. (2016). Effect of Perception of Nepotism and Employee Satisfaction on Turnover Intentions: An Empirical Study in Hospitality Enterprises, Eurasian Academy of Sciences Eurasian Business \& Economics Journal, 2: 330-339.

Zopiatis, A., Constanti, P. and Theocharous, A.L. (2014). Job Involvement, Commitment, Satisfaction and Turnover: Evidence from Hotel Employees in Cyprus, Tourism Management, 41: 129-140. 